\begin{tabular}{l}
\hline Nuansa Journal of Arts and Design \\
Volume 4 Nomor 2 September 2020 \\
e-ISSN: $2597-405 X$ dan p-ISSN: $2597-4041$ \\
\begin{tabular}{|l|l|} 
(c) This work \\
\hline (i) 4.0 International License
\end{tabular} \\
\hline
\end{tabular}

\title{
Refleksi Kritis Pada Pembelajaran Seni
}

\section{Rachmat}

\section{Corespondensi Author}

Prodi Pendidikan Seni Drama, Tari, dan Musik Fakultas Seni dan Desain Universitas Negeri Makassar

Email:

rachmat@unm.ac.id

\begin{abstract}
Education is a part of the social community, which means that the efforts to promote the growth of mind and character in order to advance the perfection of life. Arts education is a pedagogic process that aims to humanizing the art as a medium, therefore, the perpetrator in art education must have a critical awareness of the this days situation so that we can be more open about ourself and the environment around us, so it could evolve in the future orientation according to the nature of what the man himself aspired.
\end{abstract}

Keywords: education, art education, critical consciousness, a revolution.

\section{PENDAHULUAN}

\section{A. Latar Belakang}

Masa lampau memperjelas pemahaman kita terhadap masa kini, menurut $S$. Nasution sistem pendidikan yang kita miliki sekarang adalah hasil perkembangan pendidikan yang tumbuh dalam sejarah pengalaman orang terdahulu kita pada masa yang telah dilewati. Pendidikan berarti tidak berdiri sendiri tapi dipengaruhi oleh kekuatan kekuatan politik, sosial, ekonomi, kultural yang dipandang sebagai alat untuk mengatur dan menguasai perkembangan.

Manusia selalu dihadapkan dengan perubahan-perubahan sebagai akibat dari kemajuan ilmu pendidikan (pengetahuan dan teknologi), sebagai akibat dari suatu struktur sosial ekonomi baru, sebagai akibat dari revolusi politik, dimana manusia setiap kali harus menyesuaikan diri dengan keadaan keadaan baru, maka manusia tidak dapat berbuat lain dan dipaksa untuk belajar, terus menambah pengetahuan, pengertian dan pengalaman agar tidak menjadi asing terhadap masyarakat lingkungannya dan terhadap zamannya, semua menunjukkan betapa pentingnya pendidikan (Paul Lengrand. 1984). Tidak semua manusia dapat mendidik diri sendiri untuk mencapai tingkat kemanusiaan yang sesuai dengan harkat, martabat manusia itu sendiri, sehingga ini adalah kewajiban kita semua untuk menemukan caracara baru untuk menyelesaikannya, sikap dan jalan baru yang terbaik buatnya.

Kehadiran pendidikan seni menurut $A j$. Soehardjo (2012) merupakan istilah khusus yang diadopsi dari istilah asing art education yang berasal dari Amerika yang dimunculkan kurikulum sekolah di Indonesia pada kurikulum 1975 (kurang lebih berumur 41 tahun) dengan makna tertentu bukan sebagai upaya untuk mengantarkan peserta didik yang terkait dengan kompetensi kesenimannya, tetapi dengan kompetensi pendewasaan potensi individu. Pendewasaan potensi individu yang dilibatkan dalam tiga elemen yaitu mind, body dan spirit. Hal ini selaras dengan Ki Hajar Dewantara (2011) menyebutkan seni adalah segala perbuatan manusia yang timbul dari perasaan dan sifat indah, sehingga menggerakkan jiwa perasaan 


\section{Rachmat \\ Refleksi Kritis Pembelajaran Seni}

manusia. Pengertian ini lebih bersifat umum dan tidak spesifik untuk satu atau beberapa cabang seni saja, namun juga meliputi seluruh cabang seni tersebut. Karya seni juga merupakan wujud ekspresi dan perasaan estetis yang ada dalam diri manusia. Karya karya seni rupa , musik, tari, sastra, dan peran berasal dari perasaan yang dimiliki senimannya, untuk menuangkan perasaan tersebut dalam bentuk yang positif.

Berpikir kritis menurut Nuryani Suryomukti (2015) dalam bukunya Teori-teori Pendidikan menjelaskan bahwa berpikir kritis adalah sebuah kecakapan kognitif yang memungkinkan seseorang menginvestigasi sebuah situasi, masalah, pertanyaan atau fenomena agar dapat membuat sebuah penilaian atau keputusan. Dengan keadaan yang dialami di negara sendiri bahwa manusia kini diserang melalui pengetahuan dan teknologi di bidang industri yang akan berakibat pada peserta didik sendiri contohnya seperti ilusi-ilusi untuk naik kelas sosial secara pragmatis, kebanyakan orang tua menjadikan anaknya menjadi melejit dan terkenal seperti menjadi artis yang diharapkan akan menjadi mesin pencetak uang yang seakan akan bekerja sebagai penghibur. Akan tetapi, tidak sadarkah mereka membuat anaknya kehilangan waktu untuk mencari pengetahuan dan meningkatkan rasa kepeduliannya terhadap lingkungan dalam kehidupannya. Disinilah bahayanya kapitalisme bagi manusia dalam lingkungan anak-anak.

Maka tulisan ini akan membahas implementasi pendidikan seni dalam menghadapi keadaan sosial dengan menunjukkan kesadaran kritis agar terjadinya transformasi sesuai dengan identitas keadaan dan lingkungan Indonesia sendiri.

\section{B. Tinjauan Pustaka}

\section{Kesadaran kritis dan transformasi dalam pembelajaran}

Hakikat pendidikan dan mendidik, sangat bergantung dari kacamata ideologi yang digunakan ketika pendidikan harus dihadapkan dengan pesatnya perkembangan industrialisasi di era globalisasi pasar bebas dewasa ini (baca: MEA = Masyarakat Ekonomi Asean) yang sedang hangatnya di negara sendiri (baca: Indonesia) sehingga pendidikan diuji untuk mampu memberikan jawaban yang menyulitkan, yakni antara melegitimasi atau melanggengkan struktur sosial yang ada ataupun berperan kritis dalam melakukan perubahan sosial (revolusi) sesuai dengan judul diatas. Sebagai bahan perbandingan penulis meminjam pemetaan paradigma pendidikan yang digunakan oleh William O'Neil dalam bukunya Ideologi-ideologi Pendidikan, tetapi konsep yang akan dibahas pada tulisan ini adalah paradigma kritis:

1. Kritis

Pembelajaran bagi mereka merupakan arena perjuangan politik. Jika bagi konservatif pembelajaran bertujuan untuk menjaga status quo, sementara bagi kaum liberal untuk perubahan moderat, maka paradigma kritis menghendaki perubahan struktur secara fundamental dalam politik, ekonomi masyarakat di mana pembelajaran berada (Giroux, 1981). Bagi mereka kelas dan diskriminasi gender dalam masyarakat tercermin pula dalam dunia pembelajaran. Paham ini bertentangan dengan pandangan kaum liberal dimana pembelajaran dianggap terlepas dari persoalan kelas dan gender yang ada dalam masyarakat.

Dalam perspektif kritis, urusan pembelajaran adalah melakukan refleksi kritis terhadap, "the dominant ideology"e ke arah transformasi sosial. Tugas utama pembelajaran adalah menciptakan ruang agar sikap kritis terhadap sistem dan struktur ketidakadilan, serta melakukan dekonstruksi dan advokasi menuju sistem sosial yang lebih adil. Pembelajaran tidak mungkin dan tidak bisa bersikap netral, bersikap obyektif maupun berjarak dengan masyarakat (detachment) seperti anjuran positivisme. Visi pembelajaran adalah melakukan kritik terhadap sistem dominan sebagai pemihakan terhadap rakyat kecil dan yang tertindas untuk mencipta sistem sosial baru dan lebih adil. Dalam perspektif kritis, pembelajaran harus mampu menciptakan ruang untuk mengidentifkasi dan menganalisis secara bebas kritis untuk transformasi sosial. Dengan kata lain tugas utama pembelajaran adalah „memanusiakan ee kembali manusia yang mengalami dehumanisasi karena sistem dan struktur yang tidak adil.

Sehubungan dengan itu bahwa Descartes juga menyimpulkan bahwa semua pengetahuan seharusnya diturunkan dari kepastian kesadaran dan semua ilmu pengetahuan seharusnya 
dibangun diatas dasar kepastian itu. Jean paul Sartre menambahkan bahwa dalam kesadaran terdapat dua pembagian yaitu kesadaran non refelektif dan kesadaran reflektif yang mencoba untuk mengungkapkan bagi kesadaran manusia, kekuatan dan keberaniannya untuk menerima absurditas eksistensi dan kemampuannya untuk menciptakan makna dalam dunia yang tanpa makna. Selanjutnya murid dari Sartre yaitu Paulo Freire pemikir pendidikan yang optimis (abaikan: kiblat bagi penulis) yang lahir pada tanggal 19 September 1921 di Brasil yang terkenal dengan karya pemikirannya yaitu "Critical Pedagogy dan Pedagogi Politic" menggolongkan kesadaran manusia menjadi: kesadaran magical (magical consciusnes), kesadaran naif (naival consciusness), dan kesadara kritis (critical consciusness). Kesadaran magis yakni kesadaran yang tidak mampu mengetahui kaitan antara satu faktor dengan faktor yang lain, kesadaran naif yakni lebih melihat manusia menjadi penyebab masalah masyarakat, dan kesadaran kritis adalah melihat aspek sistem dan struktur sebagai sumber masalah.

Dalam konteks diatas, perlu membangun kesadaran konteks peserta didik. Kesadaran kritis merupakan kata kunci sangat penting, sebab penindasan, dominasi dan eksploitasi itu berlangsung karena terdegradasinya bagian kritis manusia. Dari beberapa filsuf diatas mereka melakukan fondasi awal dengan kesadaran krits karena pandangan kritis termasuk melakukan transformasi hubungan pendidik-peserta didik dalam perspective yang didominasi dan mendominasi. Sebaiknya dalam melakukan proses transformasi sosial (revolusi) yang juga perlu dilakukan adalah mentransformasi diri mereka dulu, yakni membongkar struktur tidak adil di dalam dunia pendidikan antara pendidik dan peserta didik.

Manusia adalah otonom, menurut $H$. A. R. Tilaar manusia memiliki banyak potensi yang bisa dikembangkan sehingga mempunyai bentuk baru atau dengan kata lain terjadi transformasi manusia itu sendiri karena manusia adalah suatu realitas yang aktif, oleh sebab itu maka sumber daya manusia haruslah dikembangkan sebagai suatu kenyataan yang tidak lepas dari kebudayaannya. Manusia mempunyai tanggung jawab utnuk memelihara dan mengembangkannya, maka lahirlah apa yang disebut aliran perenialisme, esensialisme, eksistensialisme, progresivisme (baca: telah dilalui pada semester I mata kuliah Landasan dan Kurikulum pend. Seni).

\section{Pendidikan Seni: Refleksi Kritis Menuju Transformasi}

Pendidikan seni pada awalnya adalah proses pewarisan atau dengan kata lain menularkan proses berkesenian dari generasi ke generasi yang dilakukan oleh para seniman kepada siapapun yang terpanggil untuk menjadi calon seniman. Kemudian dalam perkembangannya mulai dilembagakan pada lembaga formal maupun non-formal, dan pewarisan kesenian tidak serta merta dilakukan oleh seniman atau pelaku seni, melainkan bisa dilakukan oleh pendidik seni atau siapapun yang memiliki kemampuan berkesenian dan mampu untuk membelajarkannya. Di Indonesia sendiri pendidikan seni merupakan istilah yang diadopsi dari art education (yang mulanya berkembang di Amerika) dengan makna yang tidak terlalu ketat karena bergantung pada kepentingan, jenis, dan bentuk pendidikannya. Dalam pengertian umum pendidikan seni adalah upaya sadar untuk menyiapkan siswa melalui kegiatan pembimbingan, pembelajaran, dan pelatihan agar siswa memiliki kemampuan berkesenian. Pengalaman estetik dalam pendidikan seni diberikan melalui kegiatan apresiasi (penghargaan, penanggapan) dan kreasi (penciptaan). Di dalam kedua kegiatan tersebut terkandung aspek ekspresi (penjiwaan) ( $M$. Jazuli,2008).

Dilihat dari sisi kebahasaan, istilah pendidikan seni merupakan gabungan dua perkataan, pendidikan dan seni. Baik secara sendiri sendiri maupun hasil dari gabungannya, masing masing bukan kata kata yang baru, asing atau anehpun kedengarannya. Bahkan layak untuk dipakai sebagai sarana berkomunikasi (A.J. Soehardjo.2012).

Mengenai kompetensi pendidik akan terlihat dari kualitas dalam memahami fungsi, peran dan tugasnya. Kualifikasi tersebut dapat dikategorikan menjadi empat, yaitu (1) fungsi yang berkaitan dengan pembaharuan yang berperan sebagai komunikator, (2) fungsi pelayanan yang berperan sebagai fasilitator, (3) fungsi profesional yang berperan sebagai motivator, dan (4) fungsi tutor atau sumber informasi yang berperan sebagai reproduktor.

Penilaian yang merupakan rangkaian kegiatan untuk memperoleh, menganalisis, dan menafsirkan data tentang proses dan hasil belajar peserta didik dilakukan secara sistematis dan berkesinambungan, sehingga menjadi informasi yang bermakna dalam pengambilan keputusan. 
Penilaian harus disesuaikan dengan pengalaman belajar yang ditempuh dalam proses pembelajaran.

Lingkungan dapat mempengaruhi kualitas pribadi seseorang, dimana lingkungan yang tidak berseni dapat membuat pribadi seseorang menjadi tidak berkembang. Pikiran, jiwa dan tubuh yang tidak selaras tanpa terkecuali dalam lingkungan pendidikan formal peserta didik akan menstimulus dirinya merasa kaku, lemah ragu, cemas dan berlebihan. Keadaan lingkungan tak berseni harusnya dirubah menjadi efektif dalam pendidikan holistik. Pendidikan holistik merupakan suatu filsafat pendidikan yang berangkat dari pemikiran bahwa pada dasarnya seorang individu dapat menemukan identitas, makna dan tujuan melalui hubungan dengan masyarakat, lingkungan alam dan nilai spiritual. Peserta didik diharapkan menjadi dirinya sendiri ( learning to be ). Akibat yang terjadi dari pendidikan holistik adalah adanya kesadaran dan keinginan yang kuat untuk menyampaikan hal hal secara lengkap dan jelas dalam ekspresi manusia itu sendiri. Integrasi pikiran, tubuh dan jiwa yang harus dicapai dalam sebuah pendidikan yang akan memberikan sebuah model dari aktivitas holistik dalam mengajar seni seperti integrasi artistik dan autentik yang esensinya pada ambisi kritis.

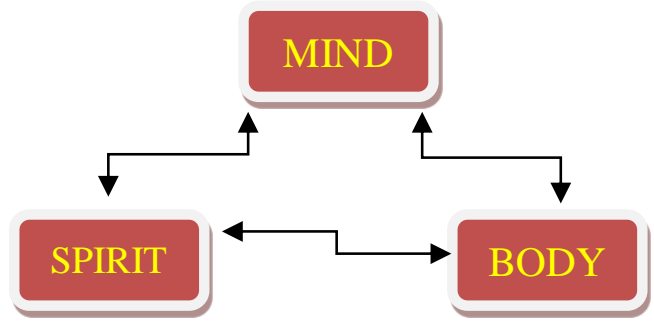

Gambar: Faktor utama dalam pendidikan seni

Dalam pendidikan seni pendidik dan peserta didik harus berperan aktif dalam proses pembelajaran. Tapi sesuai dengan realita di lapangan bahwa masih banyak pendidik yang tidak mengerti metode yang baik dalam proses pembelajaran sehingga dapat menimbulkan dominasi terhadap peserta didik. Dapat dikatakan bahwa penyelarasan antara body, mind and soul tidak seimbang. Misalnya konsep yang diterapkan yaitu konsep pendidikan gaya bank.

Pada konsep pendidikan gaya bank menggunakan pola vertikal dalam mentransfer ilmu pengetahuan yaitu mereka (pendidik) yang mengangap dirinya berpengetahuan kepada mereka (peserta didik) yang dianggap kurang memiliki pengetahuan apa-apa. Pendidik menampilkan diri di hadapan peserta didik sebagai orang yang berada pada pihak yang berlawanan (peserta didik yang kurang pengetahuan/pengalaman). Hal ini dapat mempengaruhi mental peserta didik dalam hal pengalaman estetik ini karena tidak menutup kemungkinan peserta didik mempunyai pengalaman estetik yang kurang dibanding pendidik, tiap-tiap manusia mempunyai pengalaman estetik yang berbeda beda. Tidaklah mengherankan jika konsep pendidikan gaya bank memandang peserta didik sebagai mahluk yang gampang diatur, hal ini dapat berdampak pada kurangnya kesadaran kritis pada peserta didik terhadap kesadaran mereka dalam keterlibatan dalam pendidikan formal yang cenderung menyesuaikan diri dengan apa adanya.

Mereka yang menggunakan pendekatan gaya bank ini, secara sadar atau tidak sadar tidak memahami bahwa pengetahuan yang mereka tanamkan itu berisi kontradiksi dengan realitas. Tetapi, cepat atau lambat, kontradiksi tersebut pada akhirnya akan mengarahkan peserta didik yang semula pasif dalam berproses karya seni untuk berbalik berusaha menjinakkan realitas. Mereka akan memahami lewat hubungan mereka dengan realitas bahwa realitas itu adalah sebuah proses, mengalami perubahan secara terus menerus. Jika pendidik adalah pejuang dan menyakini bahwa tujuannya adalah humanisasi, maka cepat atau lambat pendidik akan menyadari kontradiksi yang dipertahankan melalui pendidikan gaya bank bagi mereka, dan kemudian melibatkan diri ke dalam perjuangan pembebasan diri mereka dalam konsep pendidikan gaya bank ini. Usaha-usaha yang dijalankannya harus berlangsung di tengah tengah peserta didik agar mereka terlibat dalam pemikirin kritis dan daya kreatifnya serta usaha-usaha ke arah humanisasi satu sama lain. Untuk mencapai hal tersebut, pendidik mesti menjadi seorang rekan bagi peserta didik pada saat berhubungan dengan mereka. Konsep dan teori gaya bank tidak akan memungkinkan hubungan kesetiakawanan seperti itu, hal ini merampas hak mereka untuk memiliki tujuan sendiri dan memang harus demikian karena tujuan-tujuan pendidikan gaya bank ini yaitu melumpuhkan pikiran, contohnya pelajaranpelajaran verbalistik, bahan bacaan yang telah 
ditentukan, metode metode untuk menilai hasil karya dari peserta didik, media yang harus digunakan dalam berkarya, jarak antara pendidik dan peserta didik, dan ukuran ukuran dari hasil karya peserta didik. Gagasan kata orang, mustahil mekar kalau digembok dalam kandang. Gagasan hanya bisa tumbuh dewasa bila dilepas keluyuran seperti ayam kampung, gagasan pun konon niscaya mengalami padu-padan jika sasarannya adalah penemuan yang berguna bagi kemanusiaan (Omi Intan Naomi, 2015). Seluruh peserta dalam proses berpikir, temasuk semua komponen yang dipakai untuk mengubah gagasan, hanya menghasilkan manfaat bila bersekutu atau berserikat.

Sementara pendidikan gaya bank membius dan mematikan daya kreatif, maka memandang peserta didik sebagai mahluk yang bebas untuk mengaktualisasikan potensi yang ada pada dirinya yang akan memberikan kesempatan kepadanya untuk mengembangkan sesuai dengan minat dan potensi mereka, maka konsep pendidikan yang sinkron dengan pengembangan minat dan bakat mereka adalah konsep pendidikan humanis. Peserta didik adalah pribadi unik yang memiliki kemampuan dan kebutuhan untuk mengekspresikan diri atau menyatakan diri. Pendidikan seni dapat memberikan kontribusi, yaitu dengan maksud memberikan ruang berekspresi dalam pengembangan potensi kreatif dan imajinasi. Pada sekolah misalnya, sekolah memberikan ruang ekspresi diri artinya memberikan wahana untuk mengungkapkan keinginan, perasaan pikiran melalui berbagai bentuk aktivitas sesuai dengan pilihan masing masing individu sehingga menimbulkan kesenangan dan kepuasaan pribadi masing masing dan bertanggung jawab atas pilihan pilihan mereka sendiri. Pendidik dalam pembelajaran adalah memberikan pengalaman yang dapat merangsang munculnya ekspresi pribadi pada peserta didik, dengan cara memberikan beragam pengalaman dan membantu peserta didik untuk mengingat pengalaman pribadinya yang tersembunyi, dengan contoh yaitu memberikan motivasi dan merangsang motif kreasi ekspresif peserta didik agar dapat mandiri, bertanggung jawab dan terciptanya situasi dan kondisi yang bebas dalam menentukan pilihannya.

Dalam hal ini, peserta didik menjadi sebuah aktor dalam metode pengajaran dalam konsep pendidikan seni, karena peserta didik akan memahami hidupnya dalam keterlibatan dalam proses berkarya, dengan maksud peserta didik sebagai aktor bukan hanya sebagai pengamat dalam pengajaran pendidikan seni. Dalam proses pengajaran ini juga, pengetahuan tentang seni tidak dilimpahkan melainkan ditawarkan yaitu peserta didik mengadakan suatu dialog dengan pendidik maka pengetahuan yang diberikan kepada peserta didik harus menjadi pengalaman pribadi pendidik tersebut. Peran pendidik harus memberikan kebebasan kepada peserta didik memilih dan memberi mereka pengalamanpengalaman yang akan membantu mereka menemukan makna dari kehidupan mereka (peserta didik) bukan berati peserta didik boleh melakukan apa saja yang mereka suka. Pendidik menanyakan tentang ide ide yang dimiliki oleh para peserta didik dan mengajukan ide ide lain kemudian membimbing mereka untuk memilih alternative alternative, sehingga mereka melihat bahwa kebenaran tidak terjadi pada manusia melainkan dipilih oleh manusia. Pendidik harus mampu membimbing dan mengarahkan peserta didik dengan seksama sehingga siswa mampu berpikir kritis.

M. Ainul Yaqin (2005) mengatakan bahwa pendidik dan lembaga formal mempunyai peran pokok terhadap pengembangan siswa yang peduli dan kritis terhadap segala bentuk ketidakadilan sosial, ekonomi dan politik yang ada disekitarnya, dengan menumbuhkan kesadaran kritis peserta didik sejak dini terhadap segala fenomena ketidakadilan yang ada, diharapkan dapat mendorong peserta didik untuk selalu bersikap kritis terhadap keadaan atau lingkungan yang tidak adil contohnya dengan memberikan tanggung jawab kepada peserta didiknya untuk melihat fenomena sosial di lingkungan sosial mereka dan beorientasi kepada mind, body, soul yaitu membuat karya seni sesuai dengan disiplin ilmu masing-masing. Menurut saya dengan hal itu maka peserta didik sudah diasah kemampuannya dalam kesadaran kritis untuk berpikir dan bertindak secara kritis dengan berkarya dan peduli terhadap masyarakat. Misalnya yang berminat dengan disiplin ilmu musik, peserta didik bisa membuat karya dengan membuat lagu yang kritis terhadap realita sosial, begitupun dengan disiplin ilmu seni rupa, bisa saja membuat design baju atau lukisan untuk menuangkan kesadaran kritisnya. Begitupun juga dengan tari dan sastra.

Selain daripada lingkungan sosial peserta didik dalam pendidikan seni, pelaku dalam pendidikan seni mampu merasa bangga dengan keragaman etnis sesuai dengan seni dan budaya masing masing suku. Adanya pluralitas suku tentunya tidak harus membuat peserta didik yang berasal dari etnis dan ras berbeda menjadi terpecah belah 


\section{Rachmat \\ Refleksi Kritis Pembelajaran Seni}

dan saling memusuhi. Meskipun dalam sejarah ada banyak kisah sedih yang memilukan yang diakibatkan oleh pertentangan antar ras dan etnis. Contohnya dalam pendidikan formal di perguruan tinggi, bermacam-macam ras dan etnis yang ingin mendapatkan pendidikan yang sama, dalam pendidikan seni hal ini dianggap kekayaan bagi pelaku dalam pendidikan seni karena tiap-tiap ras dan etnis dapat berbagi tentang seni dan budaya mereka masing-masing sehingga dapat menambah pengetahuan baru bagi yang berbeda ras dan etnis, bekerja sama dalam membuat aransemen musik, bekerjasama dalam pertunjukan, dan managemen pertunjukan, inilah yang dimaksud dengan pendidikan seni yang multikulturalisme dan demokrasi.

\section{METODE}

Metode yang digunakan dalam pengkajian ini adalah observasi dan penelusuran pustaka.

\section{PEMBAHASAN}

Strategi teknik pendidikan multikulturalisme diabdikan unruk mencitakan generasi-generasi yang sadar akan keragaman budaya yang menurut James banks memiliki empat dimensi pokok yaitu (1) content integration yaitu mengintegrasikan berbagai budaya dan kelompok untuk mengilustrasikan konsep mendasar (2) the knowledge construction process yaitu cara / metode bagaimana persrta didik memahami implikasi budaya (3) an equity pedagogy yaitu usaha menyesuaikan metode pengajaran dengan cara belajar peserta didik dalam rangka nenfasilitasi prestasi akademik yang beragam bak dari segi ras, budaya, ataupun sosial (4) prejudice reduction yaitu melatih kelompok untuk berpartisipasi dalam kegiatan berkesenian yang berbeda etnis dan ras dalam upaya menciptakan budaya akademik, sehingga mampu mereda konflik-konflik antar ras dan etnis agar tidak terjadinya diskriminasi antar ras dan etnis, hal ini akan berujung pada transformasi sosial dalam hal humanisasi.

Pada tulisan bagian pendahuluan didepan bahwa disinggung mengenai ilusi-ilusi untuk naik kelas sosial secara pragmatis. Ini sangat berhubungan erat dengan pendidikan seni bahwa peserta didik harus melek dengan keadaan sosial seperti ini yang menyangkut tentang programprogram berkedok kesenian di layar televisi, sekarang ini bahwa kita tahu dunia selebritis adalah dunia gemerlap yang membuat kalangan ini lupa diri, terlena dan tersingkirkan dari kedalaman makna hidup, dunia pesta, dunia pamer, dunia narkoba, seks bebas, dan liberalisme-individualisme melekat pada mereka. Sebagian kecil orang telah menjadi terkenal dengan menjadi artis-selebritis. Mereka disokong besar-besaran oleh pemilik modal secara finansial karena bekerja untuk membuat para anak-anak dan remaja di masyarakat menjadi konsumtif, karenanya merekalah bintang iklan yang sama halnya sebagai pekerja pemilik modal agar produk-produknya laku. Merekalah (baca: MAFIA) yang membuat anak-anak rusak moralnya. Dengan terlena dengan lagu kacangkacangan (lagu cinta-cinta) membuat para calon generasi muda ini malas untuk membaca buku dan melakukan kegiatan pengembangan kognitif dan nalar kritisnya yang membuat anak-anak dirangsang cepat matang dan segera dimasukkan kedalam budaya kapitalisme yang melemahkan yang menyuruh mereka beli, beli dan beli. Melalui berbagai macam alat propaganda (terutama televisi) dan desain gaya hidup memang berusaha menumpulkan pola pikir dan gerak kritis yang mencecoki dengan khotbah-khotbah palsu tentang budaya pasrah, sabar, diam, menurut, dan budaya meniru (imitatif), suka-suka aja (permisif), konsumtif, dan budaya tidak mencipta (produktif dan kreatif). Tentunya ini bukan pendidikan atau penyadaran, melainkan doktrin pembodohan. Jadi disinilah terjadi reposisi bahwa seni untuk seni, dan seni untuk manusia, bahwasanya proses pengembangan mind, body and spirit perserta didik dalam karya seni kini tidak lagi dipandang dengan maksud untuk reflektif, tetapi hanya untuk menunjang kepentingan praktis lain diluar seni itu sendiri (Bambang sugiharto. 2013) sehubungan dengan RM. Soewardi dalam buku II Ki Hadjar Dewantara bahwa secara pribadi ia berpendapat, bahwa kesenian akan rusak binasalah, bila orang hendak mengarahkannya kepada mata pencaharian. Disinilah peran pendidikan seni yang merupakan proses yang mengondisikan peserta didik untuk mengenal dan mengungkapkan kehidupan yang senyatanya secara kritis. 


\section{Kesimpulan}

Pendidikan seni dapat mengahasilkan transformatif yang baik jika pendidikan yang bersifat penyadaran kritis yang memungkinkan peserta didik terintegrasi dengan realitas sosialmasyarakat dimana dia hidup. Ketika kesadaran kritis hilang bersama dengan pendidikan yang tumpul dan mengalami dekadensi, kita saksikan bagaimana bangsa ini sama sekali tak memiliki harga diri. Mengintegrasikan realitas sosial ke dalam praktik berkesenian dalam proses pendidikan seni akan membuat keluaran pendidikan tidak sekedar berkarya dan tahu banyak informasi pengetahuan, tetapi juga akan sanggup memberikan nilai praktis atas informasi yang diperolehnya.

Transformasi ternyata memerlukan individu-individu yang kritis dan kreatif, baik berupa pendidik maupun peserta didik. Di sinilah letak peranan yang besar dari pendidikan seni, yang bertujuan menghasilkan indivividu-individu yang kritis, kreatif, penuh inisiatif dan mempunyai motivasi besar untuk perubahan. Pendidikan seni adalah pendidikan dialogis, artinya proses pendidikan proses pendidikan yang terjadi merupakan proses yang membebaskan inidividu agar dapat mewujudkan proses berpikir yang kiritis, kreatif dan menginginkan perubahan, seperti yang dijelaskan dalam pandangan Paulo Freire mengenai pendidikan pemerdekaan atau pendidikan pembebasan yang tidak lain daripada pendidikan yang mengembangkan daya kritis lewat kreativitas dan inovasi individu yang dapat dilihat dari sikap terhadap realitas, persepsi terhadap peranannya dalam masyarakat, tingkat kesadaran kritis, kreativitas dan inovatif. Pribadi yang seperti inilah yang dapat menggerakkan suatu gerakan sosial untuk perubahan.

\section{DAFTAR PUSTAKA}

Ainul Yaqin, Muhammad. 2005. Pendidikan Multikultural. Yogyakarta. Nuansa Aksara.

Dewantara, Ki hadjar. 2011. Kebudayaan. Yogyakarta. Majelis Luhur Taman Siswa.

Freire, Paulo. 1999. Kehidupan, Karya, dan Pemikirannya (terjemahan). Yogyakarta. Pustaka Pelajar Offset. .2000. Pendidikan Kaum Tertindas (terjemahan). Jakarta. LP3ES Indonesia.
2007. Politik Pendidikan (terjemahan). Yogyakarta. Pustaka Pelajar. Jazuli, M. 2008. Paradigma Konstekstual Pendidikan Seni. Unesa University Press.

Lengrand, Paul. 1984. Pengantar Pendidikan Sepanjang Hayat (terjemahan). Jakarta. PT Gunung Agung.

Naomi, Omi Intan. 2015. Menggugat Pendidikan : Fundamentalis, konservatif, Liberal, Anarkis. Yogyakarta. Pustaka Pelajar.

Nasution, S. 2014. Sejarah Pendidikan Indonesia. Jakarta. PT Bumi Aksara.

O'Neil, William. 2002. Ideologi-ideologi Pendidikan (terjemahan). Yogyakarta. Pustaka Pelajar.

Sartre, Jean Paul. 2002. Eksistensialism Dan Humanisme Yogyakarta.Pustaka Pelajar Offset.

Soeharjo. 2012. Pendidikan Seni : dari konsep sampai program. Malang. Bayumedia Publishing.

Soyomukti, Nurani. 2015. Teori-teori Pendidikan Dari Tradisional Hingga Postmodern. Yogyakarta. Ar-rus Media.

Sugiharto, Bambang. 2013. Untuk Apa Seni?. Bandung. Matahari.

Tilaar, H.A.R. 2012. Perubahan Sosial dan Pendidikan. Jakarta. PT. Rineka Cipta. 